\title{
Flash floods: formation, study and distribution
}

\author{
Liudmila Kuksina ${ }^{1 *}$, and Valentin Golosov ${ }^{1,2}$ \\ ${ }^{1}$ Moscow State University, Leninskie Gory-1, GSP-1, 119991, Moscow, Russia \\ ${ }^{2}$ Instute of Geography RAS, Staromonetniy pereulok, 29, 119017, Moscow, Russia
}

\begin{abstract}
Flash floods are one of the most widespread and dangerous phenomenon on our planet. They are characterized by fast speed of development and short duration. However their study just begins because there is no one opinion what flash flood is, and there is no special term in many countries. The key reasons of their formation are intensive rainfall of short duration, location of river basin in mountain areas, and small catchment area, providing fast concentration of the runoff in river channel. Another significant factor is antecedent soil moisture. Flash floods are mostly spread in zones of subtropic, tropic and equatorial climate in the northern hemisphere. The study of flash floods is implemented in various fields of science due to hydrometeorological and lythogeomorphological causes of their formation. The important task is the differentiation of flash floods and debris flows. It can be based on the relations between sediment yield and sediments grain size and runoff characteristics with a glance of sediments concentration. The scheme of natural factors of flash floods formation is suggested with their differentiation from debris flows and floods of other types. The main issues of flash floods research and forecast are connected with small spatio-temporal scale of phenomenon and remoteness of river basins.
\end{abstract}

\section{Introduction}

Flash floods are one of the most widely-distributed and dangerous natural events on Earth. They are studied less than other types of floods due to very short formation time (less than 6 hours) and remote origin location (in mountain regions). Flash flood is fast developing but short flood originating in a few hours after causing event. But there is no unique definition for this term. In many countries (including Russia) there is no special term.

Rising population, increase of social and economical activity in areas of flash floods distribution lead to risk growth for more people and economical facilities. Such events also occur in Russia (in rivers of the Caucasus Black Sea coast, for example), but they are not defined as special type of floods often and are studied as debris flows [1] or their subtypes [2]. The main goal of this study is the analysis of flash floods origin, their distribution and study in the World, and also emphasizing of the key issues of their study and forecast.

\footnotetext{
*Corresponding author: ludmilakuksina@gmail.com
} 


\section{Origin and distribution}

The main reason (more than $85 \%$ ) of flash floods origin is high intensity rain (as the rule, convection one) with duration less than 34 hours falling in small areas. Other formation factor is relief [3] promoting rapid water and sediment flow concentration.

The maximum of liquid precipitation in the northern hemisphere falls in summerautumn period, and amount of catastrophic floods also increases during that period. Maximum amount $(20 \%)$ occurs in August, while in the period from June to November approximately $80 \%$ of flash floods occur.

Flash floods occur in subtropics, tropics, and subequatorial zone more frequent in the Northern hemisphere, but nowadays its frequency and intensity grow in regions where they have not been observed before.

Origin of flash floods differs in the USA and European countries. In the first case they occur in semiarid and arid regions, in Europe they form in more humid conditions [4].

\section{Study}

Flash floods are difficult for study due to small spatial and temporal scale of the event. Figure 1 demonstrates the regions with observed flash floods. Analysis of observed flash floods reveals vast "white" gaps. For instance, such events are known in Russia (in Krymsk, in the rivers of the Caucasus Black Sea coast), but they are not reflected in worldwide database (while the information about floods on large rivers is in the base). Among 25 fixed largest events in Europe for the last 20 years only a half is covered by standard data of hydrological observations [4].

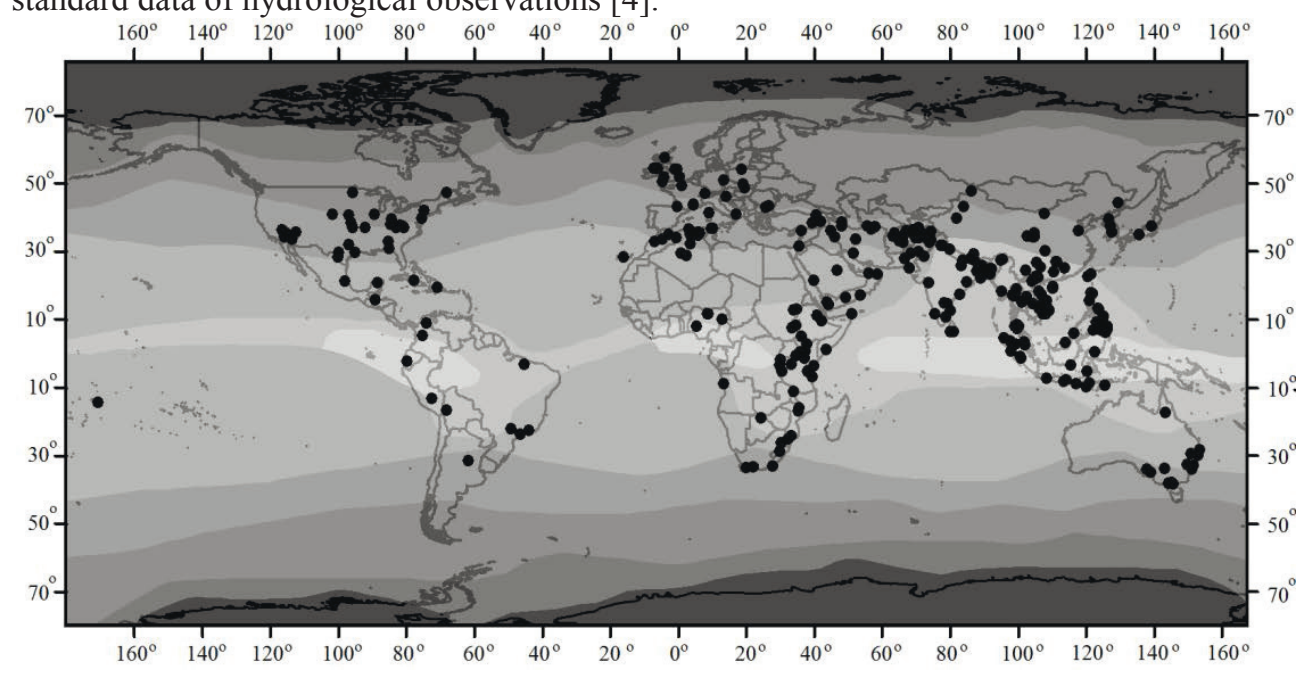

Fig. 1. Flash floods distribution in the World in various climatic zones.

Flash floods originate with combination of specified physical and geographical factors and its study is necessary to implement on the border of various natural sciences such as meteorology, hydrology and geomorphology [5].

Flash floods in the USA form in very small river basins $\left(0,125-0,312 \mathrm{~km}^{2}\right)$ due to the conditions for rapid flow concentration. Flood wave is formed faster with less basin area. For instance, lag time for a flood in basin of $0.65 \mathrm{~km}^{2}$ is approximately 40 minutes, while for basin of $165 \mathrm{~km}^{2}$ it is 5 hours [6]. Flash floods in small basins are the most destructive.

Database of extreme events in Europe [3] includes data about 550 the most extreme events in Catalonia, France, Italy, Slovakia, Greece, Romania, and Austria in 1946 - 2007. 
Database includes the data on river basin characteristics (basin area, time of flow concentration, altitude, slope, land use, and etc.), flow (minimum and maximum water discharge of various probability, flow duration, sediment yield, and etc.), precipitation (amount, duration, intensity, spatial coverage, type, etc.), data about damage. But many fields are empty due to the obstacles for monitoring (for example, there are no data about sediments in many cases), especially those parameters which are necessary to observe during the flash flood directly.

Analysis of the data demonstrates that the floods in Mediterranean regions are more extreme in comparison with incontinental regions. These results coincide with rainfall erosive index distribution in Europe very well [7].

The most extreme flash floods are usually observed in autumn (September - October in Spain and France, August - October in Italy) in Mediterranean regions, while the amount of flash floods increases in summer time (May - August) in incontinental countries.

According to [8], approximately $40 \%$ of floods in Europe are flash floods in 1950 2006. Increase of precipitation in continental [9] and global scales [10] and warming climate [11] will probably lead to increase of flash floods frequency and power also.

Complex of interconnected natural factors (such as intensive rainfalls, soil characteristics (soil moisture, soil permeability, soil thickness), relief (slope, density, basin shape) and lithology (rock steadiness to physical and chemical weathering, depth and direction of waterproof layer occurrence) and intensity of various exogenous processes) determine water and sediment discharges. Anthropogenic factors can promote increase of surface flow and washout due to the growth of crop land, urban areas and artificial forest fires.

More than $80 \%$ of flash floods in Europe occur in river basins less than $100 \mathrm{~km}^{2}$ [4]. The main morphological factors of flash flood formation are orography (promoting the development of intensive convection) and relief (promoting rapid flow concentration). The regularity intends careful studies of relief characteristics in small river basin with flash floods occurrence.

\section{Approaches to study}

One of the main tasks in flash flood study is the differentiation of flash floods and debris flows due to the absence of the common opinion about flash flood definition and its difference from debris flows. According to [12] mudflow is debris flow saturated by nonsorted solid material with a wide range in grain size composition, while the main part of sediments during flash flood is transported as suspended sediments.

In our opinion there is another difference in these phenomena. Powerful frontal wave saturated by non-sorted mix of various grain size fragments is formed during debris flow, while during flash flood increase of water discharge coincides with proportional increase of sediment flow and changes of suspended and bed load sediments mechanical composition. The suggestion is partly proofed by the results [13] where hydrological and geomorphological approach is proposed. Relation between relief ruggedness number and fan slope gives good result; they are proofed for a number of regions. Authors also mark out some transitional type between debris flows and flash floods.

Other criteria for differentiation of flash floods and debris flows could be relative concentration of sediments [14] - if $20 \%$ of flow is sediments this is water flow; if the sediment concentration exceeds $47 \%$ the flow is debris flow; in $20-47 \%$ there is a transitional type of flow.

Relation between basin area and flash flood lag time is very important for flash floods forecasting due to very short time of their development (less than 6 hours) in small river basins (less than $1000 \mathrm{~km}^{2}$ according to [4]). 
Landscape hydrology has prospects in flash floods study because it allows transfer characteristics from studied to non-studied river basins due to similarity of flow formation conditions $[4 ; 15]$. Such approach was used in precipitation analysis leading to flash floods occurrence in Alpine - Carpathian range [16]. Main processes of flash flood formation were revealed and their various combinations were represented in borders of 8 regions with relatively uniform conditions of flash flood formation.

\section{Issues of study and forecast}

There are two groups of issues in flash flood studies which demands research in details. The first one is study of flash floods formation factors interconnection. All factors could be divided into three branches: hydrometeorological, lithological and geomorphological, and anthropogenic ones. The last group (anthropogenic factors) is not the necessary element of flash flood formation, but it can promote the development of "usual" flood into extreme one.

Lithological and geomorphological factors (Fig. 2) of flash flood formation are the most easily detected. They are relatively stable in time and in space. But till the present time the influence of these factors on flash flood formation hasn't been studied.

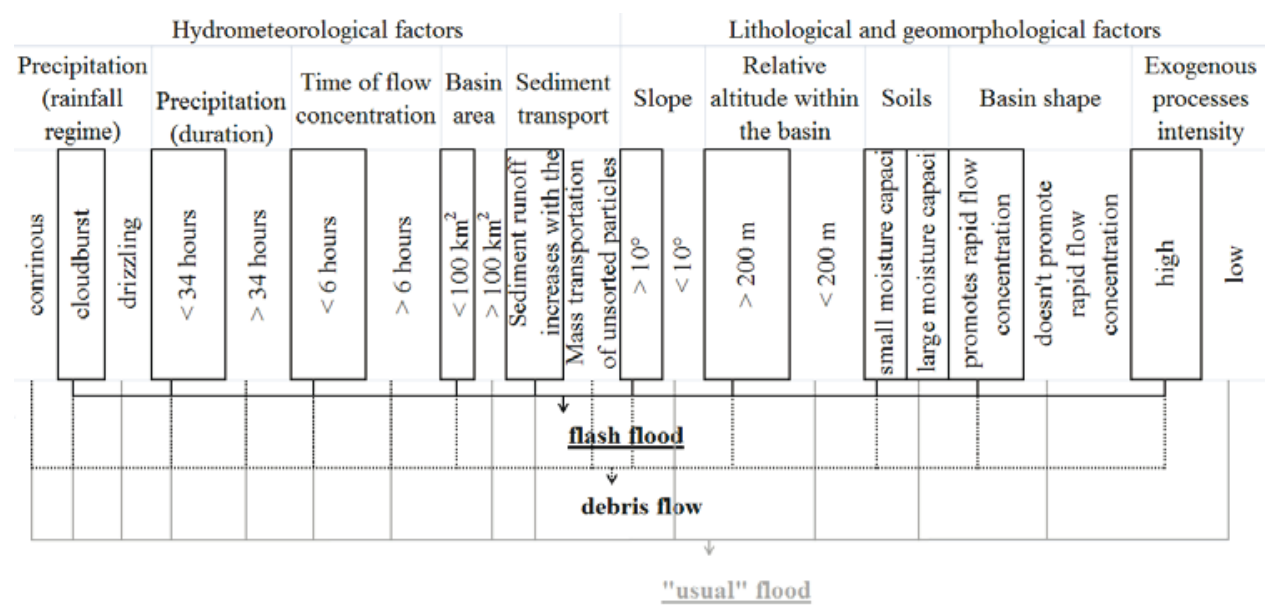

Fig. 2. Main natural factors of flash flood formation and their interaction.

Hydrometeorological factors are studied better than other groups (see Fig. 2). Although revealed regularities are regional ones and they need to be specified. Soils are on the junction of two groups. Soil formation depends on bedrock and their resistance to weathering in the current climate; on the other hand, soil moisture during intensive rainfall determines surface and interflow runoff coefficients and runoff lag time in rivers.

The second group of issues is connected with determination of river basin parameters where flash floods occur. This issue is very important for flash flood forecasting. Flash floods usually occur in small mountain river basins (less than $100 \mathrm{~km}^{2}$ ) due to rapid flow concentration. However there is often no any monitoring in such river basins (due to their small area and remoteness in mountain regions) or stations could be destroyed during flash flood. Even in case of monitoring data availability it's very complicated task to extrapolate water discharges due to significant channel transformation during flash flood [17]. The same problem concerns precipitation monitoring due to the small scale of flash flood provoking rainfalls (much smaller than precipitation monitoring network). 
Urgency of reliable forecasts of flash floods is increasing due to population growth and urban areas extension. More people are under risk of flash flood occurrence due to increase of recreational load on mountain regions.

Monitoring of flash floods includes research of channel transformation after event, radar observations of meteorological parameters, and hydrological modeling.

Precipitation forecast has special meaning for flash flood forecast, however its prediction is complicated by limited spatial and temporal scale of the event. Prediction of precipitation is very complicated task due to its high spatial and temporal variability. Monitoring network is not enough to reproduce that variability as usual. Solution of the issue could be connected with radar data application due to the spatial-temporal scale and real-time data [13].

Another group of forecasts could be based on threshold valuation assessment (precipitation, soil moisture, amount of sediments available for transportation) leading to flash flood development. The easiest way is estimation of the total precipitation depth. Soil moisture is urgent parameter for humid regions. Many methods apply combined approach.

Another important issue is estimation of water discharges (especially the maximum ones). They are often estimated after the event on the basis of channel morphometry and high water marks [18]. Hydrographs are reproduced by hydrological models with distributed parameters.

Distribution of physical and geographical factors including climate conditions has great importance for description of flash floods and application of landscape hydrological generalization. Climate influences on flash flood formation by two paths [4] - directly through various characteristics of storm events and indirectly by seasonality of precipitation and evaporation through previous condition of the river basin [19]. Climate conditions also significantly influence the erosion processes (for example, the relation between channel density and rainfall).

Relief influences the precipitation redistribution (change of precipitation with altitude variability) and rate of flow concentration. Basin slope and slope length and their dependence on basin area are the main parameters influencing on flow concentration velocity.

Amount and duration of precipitation are key factors in flash flood formation. There are three groups of events on the basis of relation between duration and amount of precipitation in 25 European countries [4]: 1) formed by rainfalls less than 7 hours and $100 \mathrm{~mm}$ (continental climate); 2) 7-22 hours, $300 \mathrm{~mm}$ (the Mediterranean and Alpine river basins); 3) 34 hours, $700 \mathrm{~mm}$ (the Mediterranean), however these events could be related to usual floods (transitional stage between flash flood and "usual" flood). Flash floods are mainly connected with mesoscale convective precipitation.

Estimation of flash flood lag time is based on two parameters - distance of flow formation geometric center from outlet cross section and flow velocity depending on hydraulic conditions such as channel slope, morphometry and roughness.

Sediment yield is almost not studied during flash floods [20]. Many studies demonstrate sediment yield significantly increase during flash flood (maximum suspended sediment concentration could be observed), but there are no any assessment of the total sediment yield.

\section{Conclusion}

Although flash floods are one of the most dangerous natural events on Earth and bring significant damage to people and economical infrastructure their study is only at the start point. There is even no uniform term for that event. Study of flash floods is very 
complicated task due to small spatial and temporal scale of the event and their origin in remote mountain regions difficult for access and monitoring organization.

The main factors of flash floods formation could be divided into three groups hydrological and meteorological, lythological and geomorphological, and anthropogenic ones. Their analysis demonstrates the main reason of flash floods origin is high intensity rainfall formed in mountain regions.

The basis for flash floods forecast is precipitation prediction with accounting of relief promoting rapid flow concentration in channel. Hydrological modeling and landscape hydrology have great prospects in flash floods studies.

The reported study was funded by RFBR according to the research project № 20-35-70035.

\section{References}

1. A.L. Shyparkov, P.K. Koltermann, Yu.G. Seliverstov, S.A. Sokratov, V.F. Perov, Vestn. Mosk. U. Geog.+, 3, 42-48 (2013)

2. V.L. Baburin, S.A. Gavrilova, P. Koltermann, Yu.G. Seliverstov, S.A. Sokratov, A.L. Shnyparkov, Geography, Environment, Sustainability, 7(3), 108-122 (2014)

3. Gaume E., Bain V., Bernardara P., Newinger O., Barbuc M., Bateman A., Blaškovičova L., Bloschl G., Borga M., Dumitrescu A., Daliakopoulos I., Garcia J., Irimescu A., Kohnova S., Koutroulis A., Marchi L., Matreata S., Medina V., Preciso E., Sempere-Torres D., Stancalie G., Szolgay J., Tsanis I., Velasco D., Viglione A., J. Hydrol., 367 (1-2), 70-78 (2009)

4. Marchi L., Borga M., Preciso E., Gaume E., J. Hydrol., 394 (1-2), 118-133 (2010)

5. Špitalar M., Gourley J., Lutoff C., Kirstetter P., Brilly M., Carr N. J. Hydrol., 519, 863-870 (2014)

6. Creutin J.D., Borga M., Lutoff C., Scolobig A., Ruin I., Creton-Cazanave L., Meteorol. Appl. 16, 115-125 (2009)

7. Panagos P., Ballabio C., Borrelli P., Meusburger K., Klik A., Rousseva S., Perčec Tadić M., Michaelides S., Hrabalíková M., Olsen P., Aalto J., Lakatos M., Rymszewicz A., Dumitrescu A., Beguería S., Alewell C., Sci. total environ., 511, 801814 (2015)

8. Barredo J.I., Nat. Hazards, 42 (1), 125-148 (2007)

9. Groisman P.Y., Knight R.W., Karl T.R., Easterling D.R., Sun B., Lawrimore J., J. Hydrometeorol., 5 (1), 64-85 (2004)

10. Groisman P.Y., Knight R.W., Easterling D.R., Karl T.R., Hegerl G.C., Razuvaev V.N., J. Climate, 18 (9), 1326-1350 (2005)

11. Huntington T.G., J. Hydrol., 319, 83-95 (2006)

12. Borga M., Stoffel M., Marchi L., Marra F., Jakob M. J. Hydrol., 518B, 194-205 (2014)

13. Costa J.E. Flood Geomorphology (John Wiley \& Sons, Chichester, England, 1988)

14. Creutin J. D., Borga M., Gruntfest E., Lutoff C., Zoccatelli D., Ruin I., J. Hydrol., 482, 14-24 (2013)

15. Parajka J., Kohnova S., Balint G., Barbuc M., Borga M., Claps P., Cheval S., Gaume E., Hlavčova K., Merz R., Pfaundler M., Stancalie G., Szolgay J., Bloschl G., J. Hydrol. 394 (1-2), 78-89 (2010)

16. Di Baldassarre G., Montanari A., Hydrol. Earth Syst. Sci., 13 (6), 913-921 (2009)

17. Chagnon S.A., J.Appl. Meteor. 17, 578-586 (1978)

18. Marchi L., Borga M., Preciso E., Sangati M., Gaume E., Bain V., Delrieu G., Bonnifait L., Pogac nik N., Hydrol. Process., 23 (26), 3761-3770 (2009)

19. Costa J.E., J. Hydrol., 93, 313-338 (1987)

20. Cohen H., Laronne J.B., Hydrol. Process., 19, 1687-1702 (2005) 